\title{
Desain dan Manufaktur Antena Heliks Oktafilar Pada Frekuensi 436,5 MHz Untuk Sistem Komunikasi Satelit
}

\author{
Heri Agus Susanto \\ Jurusan Teknik Elektro - Institut Teknologi Sepuluh November (ITS) Surabaya \\ Jl. Raya ITS, Keputih, Sukolilo, Kota Surabaya, Jawa Timur 60111, INDONESIA \\ E-mail : heriagus273@gmail.com
}

\begin{abstract}
ABSTRAK
Antena heliks oktafilar merupakan antena modifikasi dari antena heliks. Proyek akhir ini berfokus pada perancangan dan pembuatan antena heliks bifilar pada frekuensi 436,5 $\mathrm{MHz}$. Frekuensi 436,5 $\mathrm{MHz}$ merupakan frekuensi UHF-Band yang sering diaplikasikan dalam sistem komunikasi satelit saat ini. Hasil simulasi antena menunjukkan bahwa antena ini dapat bekerja pada frekuensi 436,5 $\mathrm{MHz}$.

Antena heliks oktafilar didesain menggunakan perancangan optimum berdasarkan spesifikasi yang telah ditetapkan dan dilakukan simulasi antena dengan menggunakan software CST Microwave Studio 2011 dengan hasil return loss sebesar -32,656 dB pada diameter kawat 1,5 mm dan bandwidth sebesar 7,33 MHz. sedangkan pada diameter kawat 1,5 mm, hasil return loss sebesar -23,545 dB pada diameter kawat 1,7 mm dan bandwidth sebesar 8,35 MHz. Nilai VSWR pada diameter 1,5 mm adalah 1,0477. Untuk diameter 1,7 mm VSWR sebesar 1,1425 dan gain yang diperoleh dari hasil simulasi pada diameter 1,5 mm adalah sebesar 1,99 dBi, sedangkan untuk gain pada diameter 1,7 mm sebesar 2,07 dBi.

Hasil realisasi antena pada antena heliks oktafilar menghasilkan return loss sebesar -11,21 dB pada diameter kawat 1,5 mm dan bandwidth sebesar 60,954 MHz. sedangkan hasil return loss sebesar 11,07 dB pada diameter kawat 1,7 mm dan bandwidth sebesar 90,007 MHz. Nilai VSWR pada diameter 1,5 mm adalah 1,76. Untuk diameter 1,7 mm VSWR sebesar 1,79 dan gain yang diperoleh dari hasil simulasi pada diameter 1,5 mm adalah sebesar 3,63 dBi .sedangkan untuk gain pada diameter 1,7 mm sebesar $4,15 \mathrm{dBi}$.
\end{abstract}

Kata kunci : antena heliks oktafilar, frekuensi 436,5 MHz

\section{Pendahuluan}

Saat ini sistem komunikasi satelit semakin berkembang. Seiring perkembangan tersebut, untuk membangun komunikasi satelit diperlukan antena sebagai perangkat yang berfungsi untuk mengubah sinyal listrik menjadi gelombang elektromagnetik dan sebaliknya. Antena memiliki beberapa parameter sehingga dapat digunakan untuk menunjang sistem komunikasi satelit, salah satu parameter penting dari kinerja suatu antena adalah polarisasi. Jenis polarisasi suatu antena ditentukan oleh arah medan listrik yang dipancarkan oleh antena tersebut. Dengan menggunakan sistem telekomunikasi satelit seringkali terjadi gangguan dalam transmisi dikarenakan sinyal mengalami interferensi yang menyebabkan berubahnya polarisasi. Dalam kondisi tersebut, untuk mengurangi interferensi dari sinyal yang tidak diinginkan, maka diperlukan antena dengan gain yang baik dan memiliki polarisasi sirkular.

Dengan antena berpolarisasi sirkular tidak diperlukan lagi penyesuaian antara antena pengirim dan penerima, karena antena dapat menerima sinyal dalam polarisasi horisontal, vertikal, dan miring. Selain itu, dalam pengembangan system komunikasi satelit nano digunakan frekuensi kerja yang berada pada band radio amatir UHF, sehingga dalam penelitian ini akan dirancang dan dibuat antena heliks oktafilar yang bekerja pada frekuensi 436,5 $\mathrm{MHz}$ serta memiliki polarisasi sirkular dan pola radiasi directional. Antena heliks oktafilar memiliki 8 buah filar, dimana masing-masing filar membentuk 
$1 / 2$ lilitan sehingga membuat dimensi antena menjadi tidak terlalu lebar.

\section{Antena Heliks Oktafilar}

Antena heliks oktafilar terdiri dari empat heliks bifilar identik yang diatur koaksial dengan $45^{\circ}$ untuk setiap pemisahan ruang. Gambar 2.13a menunjukkan struktur konfigurasi dari setengah belokan dari antena heliks oktafilar. Satu lengan dari antena heliks oktafilar disebut bifilar yang terdiri dari dua diagonal strip tipis berlawanan mengelilingi sekitar silinder yang melingkar dan bentuk dua elemen heliks identik terhubung radial pada bagian atas. Unsur bifilar terdiri dari konduktor berkelanjutan, yang mana terbuka pada pusat radial dari bagian bawah. Dua konduktor terbuka yang akhir menyediakan terminal feed untuk heliks. Koordinat persegi panjang dari setiap titik sembarang pada elemen bifilar dapar dihitung dengan persamaan (1) - (3) [1] :

$$
\begin{aligned}
& x=R_{o} \cos \left(u+\frac{\pi p}{2}\right) \\
& y=R_{o} \sin \left(u+\frac{\pi p}{2}\right) \\
& z=R_{o} u \tan \alpha
\end{aligned}
$$

Dimana $\mathrm{p}=0$ dan $\mathrm{p}=2$ untuk dua lengan heliks. $\mathrm{u}$ merupakan sudut dari sumbu $\mathrm{x}$, dimulai dari $\mathrm{u}=0$ and dan berakhir pada $\mathrm{u}=2 \pi \mathrm{N}, \mathrm{N}$ merupakan jumlah lilitan. Ro merupakan radius heliks. Untuk satu lilitan C merupakan circumference $(2 \pi R o)$, dan jarak antar lilitan $\mathrm{S}=\mathrm{C}$ tan $\alpha$, Untuk $\alpha$ merupakan pitch angle yang dibentuk oleh garis singgung ke kawat heliks dan sebuah plane tegak lurus dengan sumbu heliks. H merupakan panjang aksial (NS). Empat heliks identik yang digunakan pada antena heliks oktafilar merupakan feed dari ujung bawah oleh jaringan phasing menghasilkan perkembangan fase dari $45^{\circ}$ sehingga berguna pada pengendalian phasing yang mana antena meradiasikan dalam mode back fire atau end fire.

Untuk contoh desain antena heliks oktafilar seperti pada gambar 1 [1] :

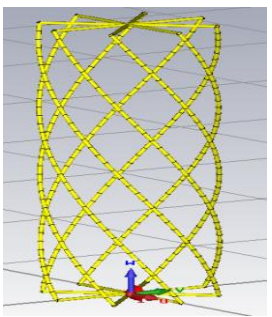

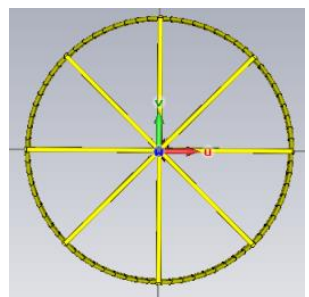

a. Tampilan Atas

b. Bentuk 3D

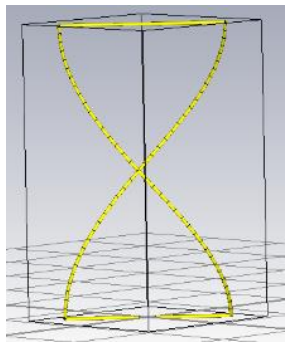

c. Setengah lilitan 1 bifilar heliks

\section{Gambar 1. Desain Antena Heliks Oktafilar}

Dari hasil perhitungan dimensi antena, diperoleh nilai dimensi antena seperti dalam tabel 1.

Tabel 1. Dimensi antena heliks oktafilar hasil perancangan

\begin{tabular}{|l|c|c|}
\hline \multicolumn{1}{|c|}{ Parameter } & $\begin{array}{c}\text { Ukuran } \\
(\mathbf{d = 1 , 5 m m})\end{array}$ & $\begin{array}{c}\text { Ukuran } \\
(\mathbf{d}=\mathbf{1 , 7} \mathbf{~ m m})\end{array}$ \\
\hline $\begin{array}{l}\text { Radius heliks } \\
\left(R_{a}\right)\end{array}$ & $40,31 \mathrm{~mm}$ & $40,31 \mathrm{~mm}$ \\
\hline $\begin{array}{l}\text { Panjang aksial } \\
(H)\end{array}$ & $182,13 \mathrm{~mm}$ & $182,13 \mathrm{~mm}$ \\
\hline $\begin{array}{l}\text { Tinggi lilitan } \\
\left(L_{a}\right)\end{array}$ & $141.801 \mathrm{~mm}$ & $143.821 \mathrm{~mm}$ \\
\hline $\begin{array}{l}\text { Panjang filar } \\
(\text { Perimeter })\end{array}$ & $2749,2 \mathrm{~mm}$ & $2749,2 \mathrm{~mm}$ \\
\hline Pitch angle $(\alpha)$ & $59,35^{\circ}$ & $59,35^{\circ}$ \\
\hline
\end{tabular}

\section{Desain antena}

Dalam desain dari antena, ada beberapa kriteria yang harus dipenuhi untuk desain dari antena agar dapat bekerja dengan baik yaitu axial ratio $<3 \mathrm{~dB}$, return loss $<-10 \mathrm{~dB}$ dan VSWR $<2$. Pada tabel 2 terdapat spesifikasi dari antena [4] [5]. 
Tabel 2. Spesifikasi antena

\begin{tabular}{|l|l|}
\hline \multicolumn{1}{|c|}{ Parameter } & \multicolumn{1}{c|}{ Spesifikasi } \\
\hline Frekuensi & $436,5 \mathrm{MHz}$ \\
\hline Bandwidth & $7,6 \mathrm{kHz}-100 \mathrm{MHz}$ \\
\hline Axial Ratio & $<3 \mathrm{~dB}$ \\
\hline Polarisasi & Sirkular \\
\hline Return Loss & $<-10 \mathrm{~dB}$ \\
\hline VSWR & $<2$ \\
\hline
\end{tabular}

\section{Simulasi dan Hasil Parameter Antena}

Simulasi pada antena heliks oktafilar dengan menggunakan software CST Microwave Studio 2011 dilakukan variasi jenis diameter kawat tembaga (d) yaitu 1,5mm dan 1,7 mm. Feeder dari antena heliks oktafilar menggunakan discreate port dengan impedansi input dibuat normalisasi sebesar $50 \mathrm{Ohm}$ dan mengcompile proses menggunakan transcient solver.

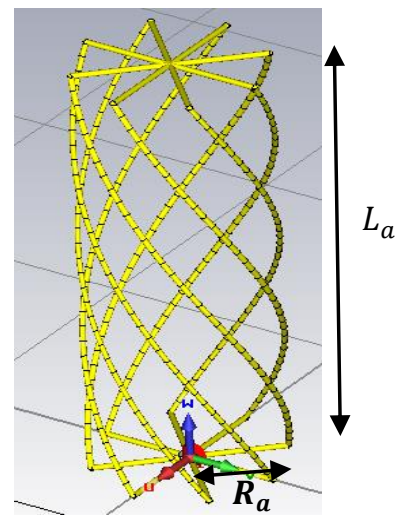

Gambar 2. Konstruksi dari antena heliks oktafilar

Konstruksi antena heliks oktafilar pada CST Microwave Studio 2011 dibuat berdasarkan dimensi hasil perhitungan seperti pada tabel 1 . Dalam simulasi dapat dihasilkan nilai dari beberapa parameter seperti return loss, VSWR, gain, axial ratio, pola radiasi dan polarisasi. Hasil dari simulasi pada antena heliks oktafilar seperti berikut :

\section{Return Loss}

Nilai return loss yang dijadikan acuan adalah $-10 \mathrm{~dB}$. Hasil simulasi Pada $\mathrm{d}=1,5 \mathrm{~mm}$ menunjukkan bahwa nilai return loss di bawah -10 $\mathrm{dB}$ mulai dari frekuensi $432,84 \mathrm{MHz}$ hingga $440,17 \mathrm{MHz}$ dan pada frekuensi kerja 436,5 MHz nilai return loss-nya adalah $-32,656 \mathrm{~dB}$.

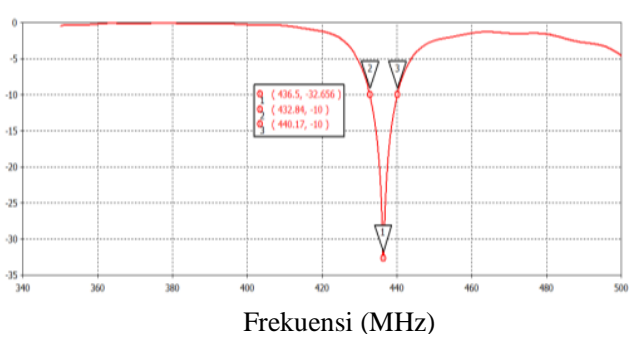

Gambar 3. Grafik S11 OHA d=1,5mm

Untuk $\mathrm{d}=1,7 \mathrm{~mm}$ pada hasil simulasi menunjukkan bahwa nilai return loss di bawah -10 dB mulai dari frekuensi 432,43 $\mathrm{MHz}$ hingga 440, $78 \mathrm{MHz}$. Dan pada frekuensi kerja 436,5 $\mathrm{MHz}$ nilai return loss-nya adalah $-23,574 \mathrm{~dB}$.

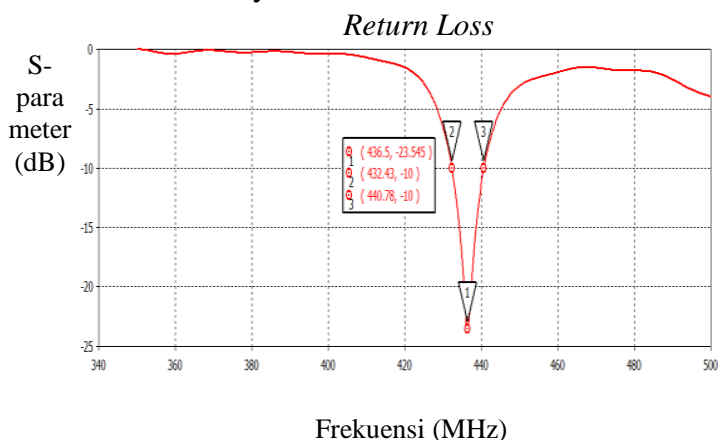

Gambar 4. Grafik S11 OHA d=1,7 mm

\section{VSWR}

Nilai VSWR maksimum yang dapat ditoleransi adalah 2. Hasil simulasi pada $\mathrm{d}=1,5 \mathrm{~mm}$ menunjukkan nilai VSWR di bawah 2 adalah pada frekuensi 432,68 MHz sampai 440,36 MHz dan pada frekuensi kerja $436,5 \mathrm{MHz}$ nilai VSWRnya adalah 1,0477 .

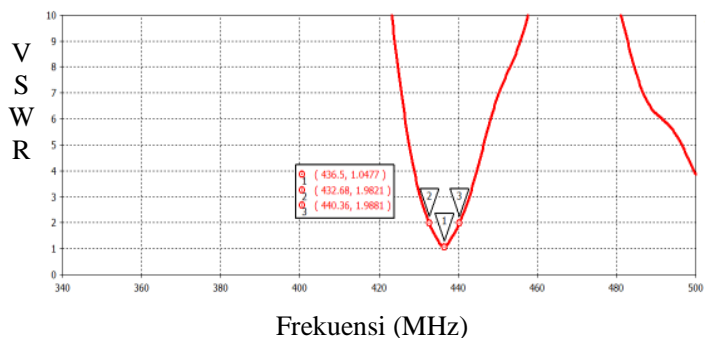

Gambar 5. Grafik VSWR OHA d=1,5 mm

Hasil simulasi pada $\mathrm{d}=1,7 \mathrm{~mm}$ menunjukkan nilai VSWR di bawah 2 adalah pada frekuensi $432,54 \mathrm{MHz}$ sampai 440,56 $\mathrm{MHz}$ dan pada frekuensi kerja 436,5 MHz nilai VSWRnya adalah 1,1425 . 


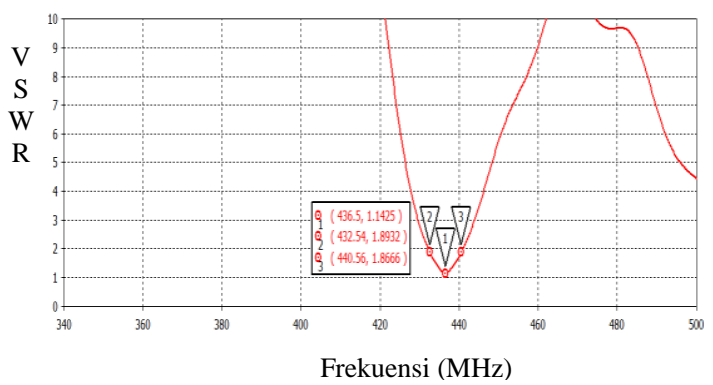

Gambar 6. Grafik VSWR OHA d=1,7 mm

\section{Pola Radiasi}

Hasil simulasi pada $\mathrm{d}=1,5 \mathrm{~mm}$ menunjukkan pola radiasi antena heliks oktafilar hasil rancangan adalah directional dengan main lobe magnitude sebesar $1,986 \mathrm{~dB}$ pada sudut $0^{\circ}$.

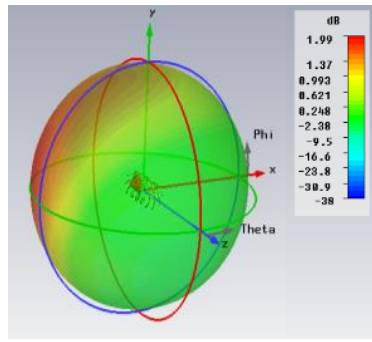

a. Bentuk 3D

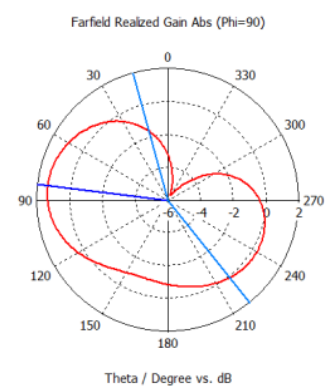

b. Bentuk Polar
Gambar 7. Pola radiasi OHA pada $d=1,5 \mathrm{~mm}$

Dalam koordinat polar, pola radiasi antena heliks oktafilar memiliki HPBW sebesar 203,1 ${ }^{\circ}$ pada $\mathrm{d}=1,5 \mathrm{~mm}$. Sedangkan, ketika $\mathrm{d}=1,7 \mathrm{~mm}$ menunjukkan pola radiasi antena heliks oktafilar hasil rancangan adalah directional dengan main lobe magnitude sebesar $2,067 \mathrm{~dB}$ pada sudut $0^{\circ}$.

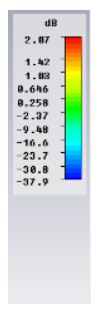

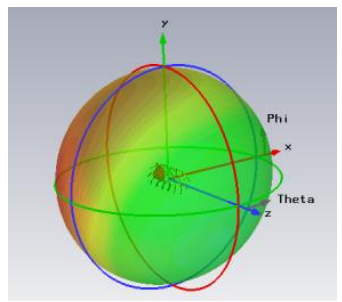

a. Bentuk 3D

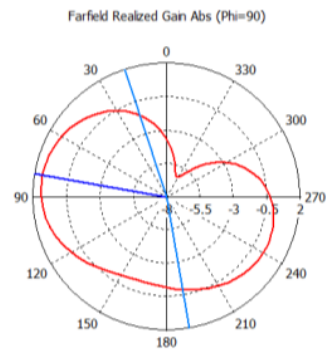

Theta / Degree vs. dB
Gambar 8. Pola radiasi OHA pada $\mathrm{d}=1,7 \mathrm{~mm}$

4. Polarisasi

Hasil simulasi polarisasi ditunjukkan oleh nilai axial ratio dalam fungsi sudut. Nilai axial ratio sendiri merupakan perbandingan antara nilai medan E pada posisi horizontal dengan nilai medan E pada posisi vertikal seperti pada persamaan ( $2.12-2-15)$.

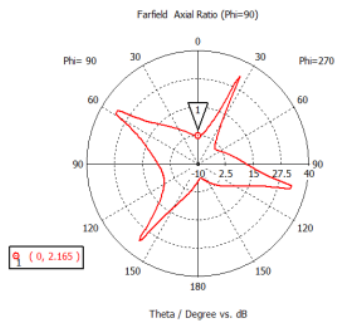

a) $\mathrm{d}=1,5 \mathrm{~mm}$

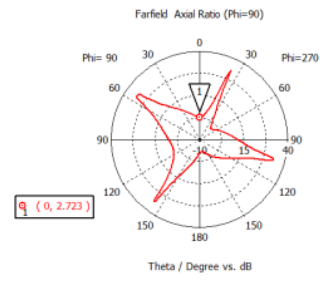

b) $\mathrm{d}=1,7 \mathrm{~mm}$
Gambar 9. Axial ratio OHA hasil simulasi

Grafik axial ratio dalam simulasi pada $\mathrm{d}=1,5 \mathrm{~mm}$ menunjukkan bahwa pada sudut $0^{\circ}$ nilai axial ratio dari antena heliks oktafilar adalah 2,165 dB. Nilai axialratio dibawah $3 \mathrm{~dB}$ menunjukkan bahwa antena heliks oktafilar hasil simulasi memiliki polarisasi sirkular.

Grafik axial ratio dalam simulasi pada $\mathrm{d}=1,7 \mathrm{~mm}$ menunjukkan bahwa pada sudut $0^{\circ}$ nilai axial ratio dari antena heliks oktafilar adalah 2,723 dB. Nilai axial ratio dibawah $3 \mathrm{~dB}$ menunjukkan bahwa antena heliks oktafilar hasil simulasi memiliki polarisasi sirkular.

Dari simulasi juga dapat diketahui bahwa hasil rancangan antena heliks oktafilar pada 
diameter kawat tembaga $(\mathrm{d})=1,5 \mathrm{~mm}$ memiliki polarisasi sirkular jenis RHCP karena nilai gain pada right polarization lebih besar dari pada left polarization yang ditunjukkan pada Gambar 10 . Dimana nilai gain pada saat LHCP sebesar -0,3916 $\mathrm{dB}$, sedangkan gain pada RHCP adalah sebesar $0,9487 \mathrm{~dB}$.

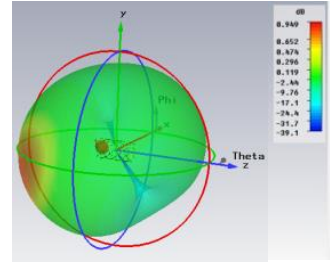

a.Right polarization

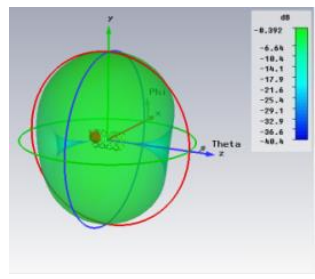

b. Left polarization
Gambar 10. Polarisasi sirkular 3D d=1,5 mm

Sedangkan, hasil simulasi antena heliks oktafilar pada diameter kawat tembaga $(\mathrm{d})=1,7$ $\mathrm{mm}$ memiliki polarisasi sirkular jenis RHCP karena nilai gain pada right polarization lebih besar dari pada left polarization yang ditunjukkan pada Gambar 11. Dimana nilai gain pada saat LHCP sebesar -0,2558 dB, sedangkan gain pada RHCP adalah sebesar $0,8720 \mathrm{~dB}$.

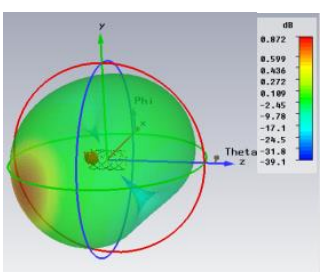

a. Right polarization $\quad b$. Left polarization

\section{Hasil Realisasi Antena}

Berikut ini merupakan hasil realisasi antena yang tersusun dari bahan kawat tembaga dengan diameter $1,5 \mathrm{~mm}$ dan $1,7 \mathrm{~mm}$.

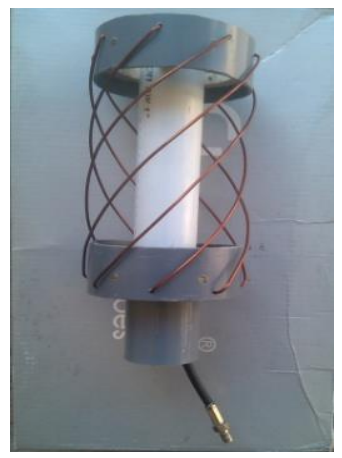

(a) Diameter (d) $=1,5 \mathrm{~mm}$

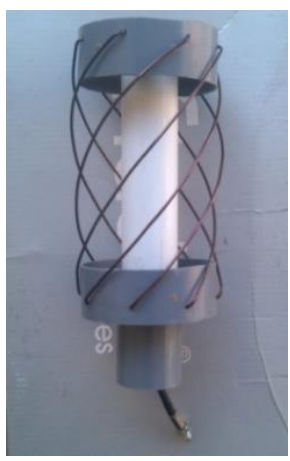

(b). Diameter (d) =1,7 mm
Gambar 12. Hasil realisasi antena OHA

\section{Pengujian}

\section{A. Return Loss}

Hasil pengujian nilai return loss dapat dilihat pada gambar 20. Dari hasil pengujian nilai return loss antena heliks oktafilar dengan diameter kawat 1,5 mm diperoleh pada frekuensi 436,5 $\mathrm{MHz}$ memiliki nilai return loss $-11,21 \mathrm{~dB}$. Nilai tersebut sesuai dengan kriteria desain dimana nilai S11 pada frekuensi kerja $(436,5 \mathrm{MHz})$ harus di bawah $-10 \mathrm{~dB}$.

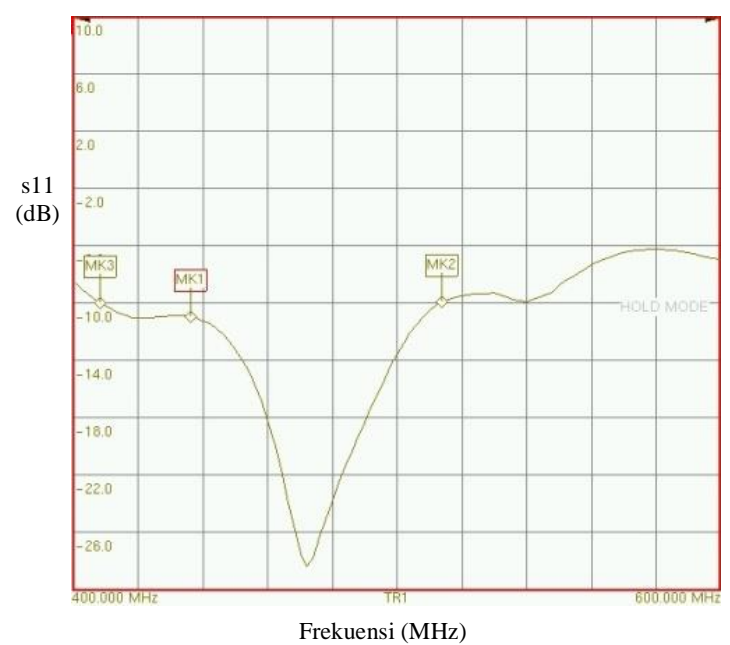

Gambar 13. Grafik S11 parameter OHA $1,5 \mathrm{~mm}$ hasil pengujian

Pada hasil pengujian pada Gambar 14, nilai return loss antena heliks oktafilar dengan diameter kawat 1,7 mm diperoleh pada frekuensi 436,5 $\mathrm{MHz}$ memiliki nilai return loss $-11,07 \mathrm{~dB}$. Nilai tersebut sesuai dengan kriteria desain dimana nilai return loss pada frekuensi kerja $(436,5 \mathrm{MHz})$ harus di bawah $-10 \mathrm{~dB}$. 


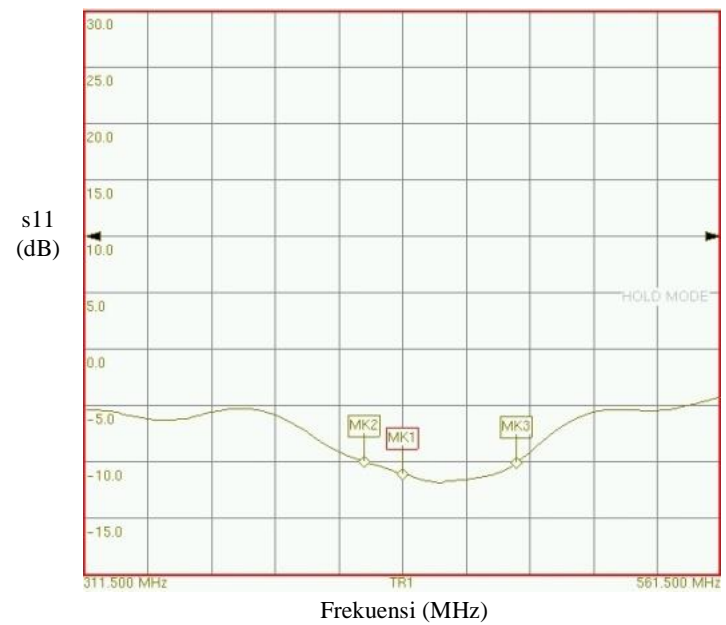

Gambar 14. Grafik S11 parameter OHA $1,7 \mathrm{~mm}$ hasil pengujian

B. VSWR

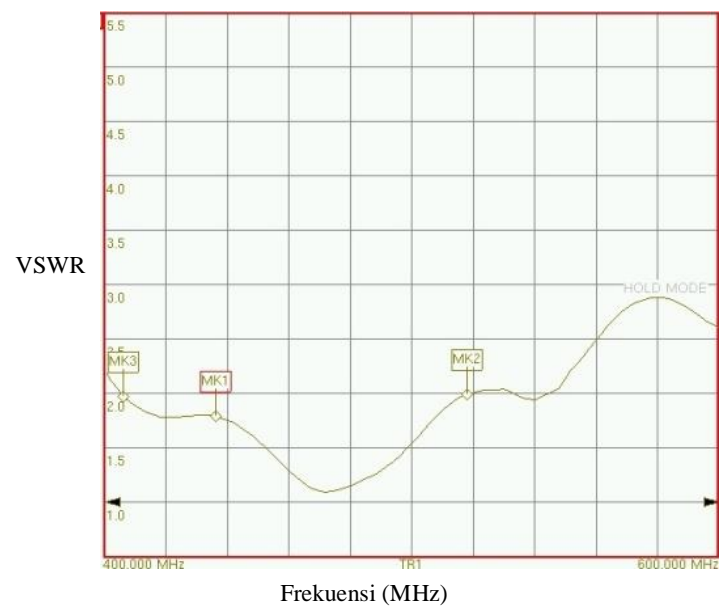

Gambar 15. VSWR OHA 1,5 mm hasil pengujian

MK1 menyatakan nilai VSWR yang berada pada frekuensi 436,5 $\mathrm{MHz}$ sebesar 1,76. MK2 adalah marker yang menandai nilai VSWR pada frekuensi 421,924 MHz sebesar 1,95. Sedangkan MK3 adalah marker yang menujukkan nilai VSWR pada frekuensi 482,878 MHz sebesar 1,95. MK2 dan MK3 adalah nilai return loss pada $-10 \mathrm{~dB}$.

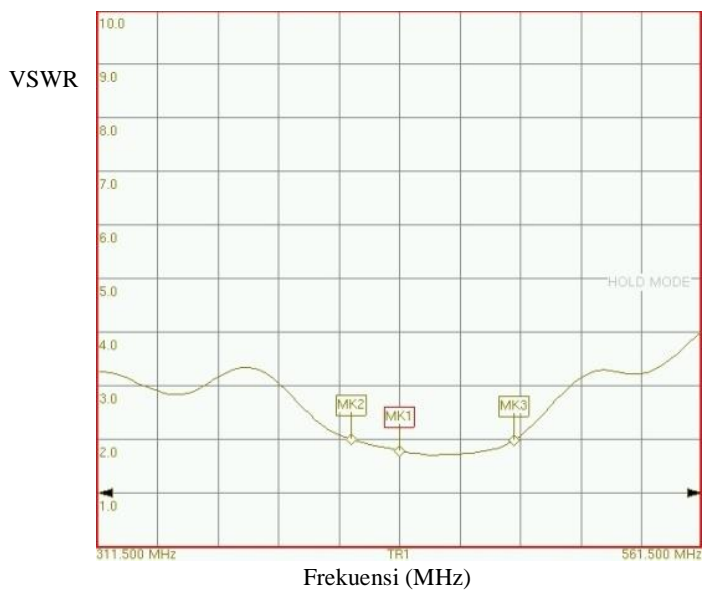

Gambar 16. VSWR OHA 1,7 mm hasil pengujian

MK1 menyatakan nilai VSWR yang berada pada frekuensi 436,5 $\mathrm{MHz}$ sebesar 1,79. MK2 adalah marker yang menandai nilai VSWR pada frekuensi 500,487 MHz sebesar 1,95. Sedangkan MK3 adalah marker yang menujukkan nilai VSWR pada frekuensi 410,480 MHz sebesar 1,95. MK2 dan MK3 adalah nilai return loss pada $-10 \mathrm{~dB}$.

\section{Gain}

Pada gambar 17 didapatkan hasil pengukuran gain antena heliks oktafilar dengan diameter kawat tembaga $1,5 \mathrm{~mm}$ pada frekuensi $436,5 \mathrm{MHz}$ sebesar 3,63 dBi.

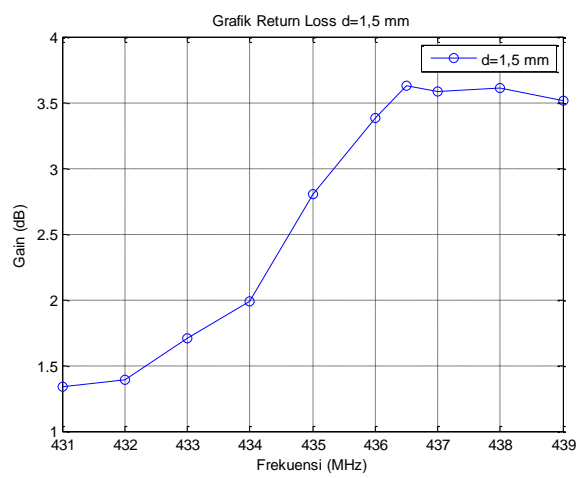

Gambar 17. Grafik plot menggunakan matlab untuk hasil pengukuran gain $\mathrm{d}=1,5 \mathrm{~mm}$.

Pada gambar 18 didapatkan hasil pengukuran gain antena heliks oktafilar dengan diameter kawat 
1,7 mm pada frekuensi 436,5 $\mathrm{MHz}$ sebesar 4,18 dBi.

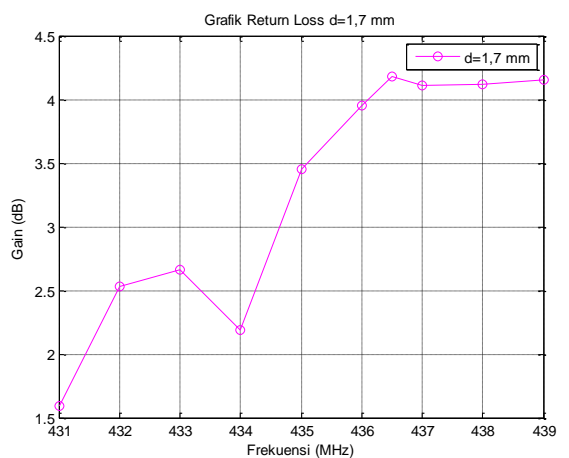

Gambar 18. Grafik plot menggunakan matlab untuk hasil pengukuran gain $\mathrm{d}=1,7 \mathrm{~mm}$

D. Pola Radiasi
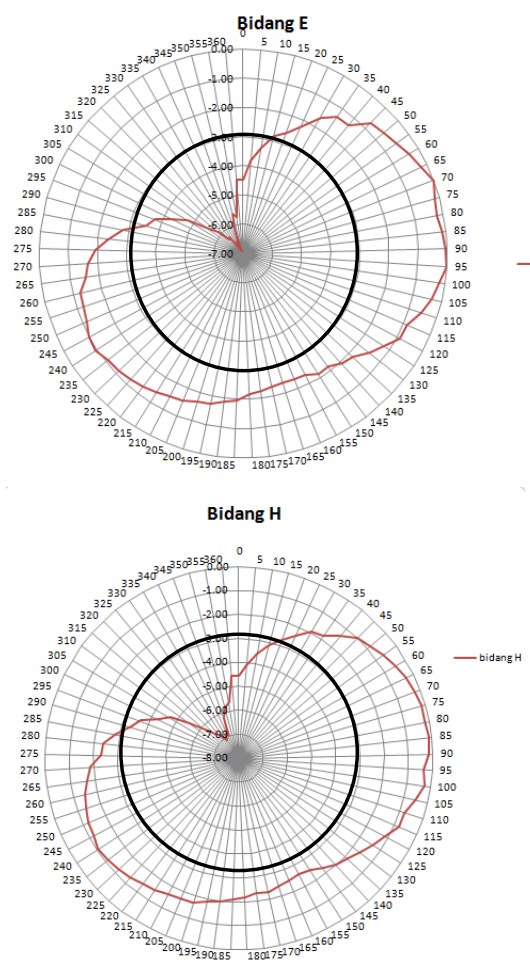

Gambar 19. Pola radiasi OHA bidang E dan bidang $\mathrm{H}$ pada $\mathrm{d}=1,5 \mathrm{~mm}$
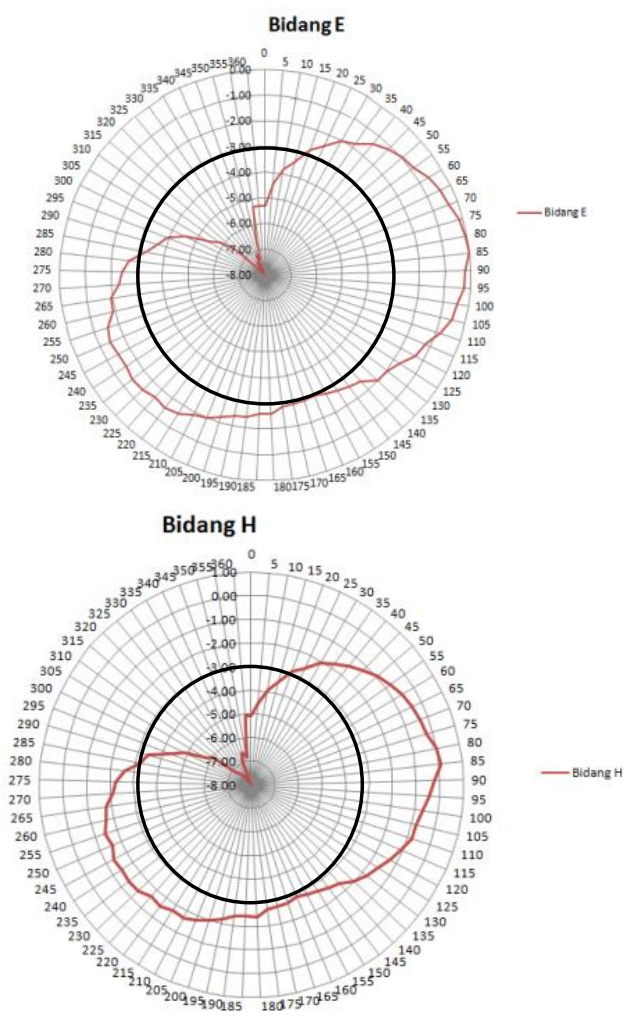

Gambar 20. Pola radiasi OHA bidang E dan bidang $\mathrm{H}$ pada $\mathrm{d}=1,7 \mathrm{~mm}$

Dari gambar pola radiasi diatas terlihat bahwa garis berwarna merah mewakili hasil pengukuran level daya yang diterima oleh antena dan garis berwarna hitam adalah letak $-3 \mathrm{~dB}$.

Magnitude yang di-plot pada setiap sudut merupakan hasil normalisasi daya yang terukur. Antena heliks oktafilar mempunyai daya yang paling besar ketika berada pada sudut 85 derajat.

Tabel 3. Perbandingan Hasil Simulasi \& Pengukuran

\begin{tabular}{|c|c|c|c|c|}
\hline \multirow{2}{*}{$\begin{array}{c}\text { Param } \\
\text { eter }\end{array}$} & \multicolumn{2}{|c|}{ Hasil Simulasi } & \multicolumn{2}{c|}{$\begin{array}{c}\text { Hasil } \\
\text { Pengukuran }\end{array}$} \\
\cline { 2 - 5 } & $\begin{array}{c}\mathrm{d}=1,5 \\
\mathrm{~mm}\end{array}$ & $\begin{array}{c}\mathrm{d}=1,7 \\
\mathrm{~mm}\end{array}$ & $\begin{array}{c}\mathrm{d}=1,5 \\
\mathrm{~mm}\end{array}$ & $\begin{array}{c}\mathrm{d}=1,7 \\
\mathrm{~mm}\end{array}$ \\
\hline & $\begin{array}{c}432,84 \\
\mathrm{MHz}\end{array}$ & $\begin{array}{c}432,43 \\
\mathrm{MHz}\end{array}$ & $\begin{array}{c}421,92 \\
4 \mathrm{MHz}\end{array}$ & $\begin{array}{c}410,4 \\
8 \\
\mathrm{MHz}\end{array}$ \\
\hline
\end{tabular}




\begin{tabular}{|c|c|c|c|c|}
\hline kerja & $\begin{array}{c}440,17 \\
\mathrm{MHz}\end{array}$ & $\begin{array}{c}440,78 \\
\mathrm{MHz}\end{array}$ & $\begin{array}{c}482, \\
878 \\
\mathrm{MHz}\end{array}$ & $\begin{array}{c}500 \\
, 48 \\
7 \\
\mathrm{M} \\
\mathrm{Hz}\end{array}$ \\
\hline $\begin{array}{c}\text { Return } \\
\text { loss } \\
(436,5 \\
\text { MHz) } \\
\end{array}$ & $\begin{array}{c}-32,656 \\
\mathrm{~dB}\end{array}$ & $-23.545 \mathrm{~dB}$ & $-11,21 \mathrm{dH}$ & $\begin{array}{l}- \\
11,07 \\
\mathrm{~dB}\end{array}$ \\
\hline $\begin{array}{c}\text { Bandw } \\
\text { idth }\end{array}$ & $\begin{array}{l}7,33 \\
\mathrm{MHz}\end{array}$ & $8,35 \mathrm{MHz}$ & $\begin{array}{c}60,954 \\
\mathrm{MHz}\end{array}$ & $\begin{array}{c}90,00 \\
7 \\
\mathrm{MHz}\end{array}$ \\
\hline $\begin{array}{l}\text { Axial } \\
\text { ratio }\end{array}$ & $\begin{array}{c}2,15 \\
\mathrm{~dB}\end{array}$ & $2,72 \mathrm{~dB}$ & $1,28 \mathrm{~dB}$ & $\begin{array}{c}1,59 \\
d B\end{array}$ \\
\hline VSWR & 1,0477 & 1,1425 & 1,76 & 1,79 \\
\hline Gain & $\begin{array}{c}1,986 \\
\mathrm{dBi}\end{array}$ & $2,067 \mathrm{dBi}$ & $3,63 \mathrm{dBi}$ & $\begin{array}{l}4,15 \\
d B i\end{array}$ \\
\hline
\end{tabular}

\section{Kesimpulan}

1. Antena heliks oktafilar bekerja pada range frekuensi 436,5 $\mathrm{MHz}$ menghasilkan return loss $-11,21 \mathrm{~dB}$ pada $\mathrm{d}=1,5 \mathrm{~mm}$ dan menghasilkan return loss pada $\mathrm{d}=1,7 \mathrm{~mm}$ sebesar $11,07 \mathrm{~dB}$.

2. Bandwidth pada $\mathrm{d}=1,5 \mathrm{~mm}$ sebesar $60,954 \mathrm{MHz}$ dan pada $\mathrm{d}=1,7 \mathrm{~mm}$ menghasilkan bandwidth sebesar 90,007 MHz.

3. Pada kedua diameter kawat tembaga pada antena heliks oktafilar mempunyai polarisasi sirkular karena nilai axial ratio kurang dari $3 \mathrm{~dB}$.

4. Gain yang dihasilkan dari realisasi antena lebih besar dari hasil simulasi yaitu pada $\mathrm{d}=1,5 \mathrm{~mm}$ menghasilkan gain $3,63 \mathrm{dBi}$ dan pada $\mathrm{d}=1,7 \mathrm{~mm}$ menghasilkan gain sebesar $4,15 \mathrm{dBi}$.

5. Perbedaan hasil pengukuran yang tidak sesuai dengan hasil simulasi dapat disebabkan oleh kesalahan pada proses fabrikasi yang mengakibatkan adanya ketidakpresisian proses pembuatan antena, terutama dari segi dimensi, sehingga hal tersebut sangat berpengaruh pada hasil pengukuran.

\section{Referensi}

[1] Saber H. Zainud-Deen, Hend A. Malhat dan Kamal H. Awadalla, "Octafilar Helical Antenna for Portable UHF-RFID Reader", International Journal of Engineering Business Management

Special Issue on Radio Frequency Identification and Wireless Sensor Networks, 2012.

[2] Violita, Desain Antena Heliks Quadrifilar pada Frekuensi 2,4 GHz Untuk Perangkat Ground Station Satelit Nano. Jurnal Teknik POMITS Vol. 2, 2013.

[3] C. A. Balanis, "Broadband Antenna", Chapter 10 in Antennas Theory, IEEE PRESS, 2001

[4] G. I. McKerricher, and J. S. Wight, “ Quadrifilar Helical Antenna for UHF RFID”, in Proc. IEEE Antenna and Propagation Soc. Int. Symp., Vol. 1, June 2010.

[5] S. H. Zainud-Deen, N. M. Salem, S. M. Ibrahem, and H. A. Moaafy," Investigation of an octafilar helix antenna," 9th International Symposium on Antennas Technology and Applied Electromagnetics, ANTEM, pp. 542545, July 2002, Manitoba, Canada.

[6] Amrullah Y.S., Desain Antena Monopole UHF untuk Uplink pada Satelit Iinusat-02, Jurnal Teknik ITS Vol.1, 2012.

[7] Alan Sujadi, Desain Antena Microstrip dengan Tapered Peripheral Slits Untuk Payload Satelit Nano Pada Frekuensi 436,5 MHz, Jurnal Teknik ITS Vol.1, 2012.

[8] Maxwell M.W., Chapter 22 "The Quadrifilar Helix Antenna" in ARRL book "Reflection", CQ Communications, Inc., 1991.

[9] Marais S.J., Chapter 2 "The Quadrifilar Helix Antenna" in book "The Quadrifilar Helix Antenna and its Application to Wide Angle Phase-Steered Arrays",Stellenbosch University, 2007.

[10] S. H. Zainud-Deen, N. M. Salem, S. M. Ibrahem, and H. A. Moaafy," Octafilar helix antennas for mobile satellite handsets," in 
Proc. IEEE Antennas and Propagation Soc. Int. Symp., Vol. 1, June 2003, USA.

[11] Budi Aswoyo, "Studi Perbandingan Efisiensi Bahan Pada Pembuatan Antena Horn Sektoral Bidang Medan Listrik (E) ", PENSITS, Surabaya, 2007.tena Microstrip dengan Tapered Peripheral 